\title{
The Catabolism of Arginine by Pseudomonas aeruginosa
}

\author{
By M. RAHMAN, $\uparrow$ P. D. LAVERACK AND PATRICIA H. CLARKE* \\ Department of Biochemistry, University College London, Gower Street, London WC1E 6BT
}

(Received 18 May 1979)

\begin{abstract}
Mutants isolated from Pseudomonas aeruginosa strain PAO1632 ( $\mathrm{Hut}^{-} \mathrm{Ami}^{-}$) were unable to utilize L-arginine or L-ornithine as the carbon source for growth. Arginine deiminase (AD), catabolic ornithine carbamoyltransferase (cOTC) and $N^{2}$-acetylornithine 5-aminotransferase (ACOAT) were present in the mutants but these enzymes were not induced to higher levels by exogenous L-arginine. One group of mutants could utilize L-ornithine but not $\mathrm{L}$-arginine and in these strains L-arginine induced the synthesis of ACOAT but not AD or cOTC. The mutations of the arginine utilization-negative mutants were all in genes of the same transductional linkage group and mapped in the 45 to 50 min region of the chromosome. Revertants isolated on L-arginine or L-ornithine plates were derepressed for the synthesis of ACOAT. It is suggested that L-arginine is normally catabolized by the wild-type strain via the arginine deiminase pathway and requires a threshold level of ACOAT. The regulatory factors controlling the functioning of the divergent arginine deiminase and arginine carboxylase pathways are discussed.
\end{abstract}

\section{INTRODUCTION}

Most strains of Pseudomonas aeruginosa can utilize L-arginine for growth (Stanier et al., 1966). Figure 1 shows some of the reactions. One route starts with a group of three enzymes: arginine deiminase (1) producing citrulline; ornithine carbamoyltransferase (2) producing ornithine and carbamoylphosphate; and carbamate kinase (3) producing $\mathrm{CO}_{2}$ and ATP from carbamoylphosphate. These are the reactions of 'arginine dihydrolase' and account for the slight growth and the motility of this aerobic organism in complex media under anaerobic conditions (Shoesmith \& Sherris, 1960). One of these steps is formally the reverse of an enzymic step of arginine synthesis but the catabolic ornithine carbamoyltransferase (cOTC) is quite distinct from the anabolic ornithine carbamoyltransferase (aOTC), which is the only one of the arginine biosynthetic enzymes to be severely repressed by arginine (Haas et al., 1977). cOTC is induced by arginine (Stalon et al., 1967) and in vivo the two ornithine carbamoyltransferases act unidirectionally for the biosynthesis and catabolism of arginine, respectively (Stalon et al., 1972, 1977). Voellmy \& Leisinger (1972) found that one of the biosynthetic enzymes, $N^{2}$-acetylornithine 5-aminotransferase (ACOAT), is induced about 15-fold during growth with arginine. ACOAT also acts on ornithine (4) and they suggested that it plays a role both in the biosynthesis and in the catabolism of arginine (Voellmy \& Leisinger, 1975).

An alternative pathway is initiated by arginine decarboxylase (5) producing agmatine which can be converted to putrescine $(6,7)$ (Mercenier et al., 1980). Jacoby \& Fredericks (1959) reported that $P$. fluorescens catabolized putrescine via 4-aminobutyraldehyde and Stanier et al. (1966) found that most strains of $P$. aeruginosa could utilize putrescine for growth. The decarboxylation of ornithine (8) can also give rise to putrescine (Stalon et al., 1967).

$\dagger$ Present address: University of Dacca, Bangladesh. 


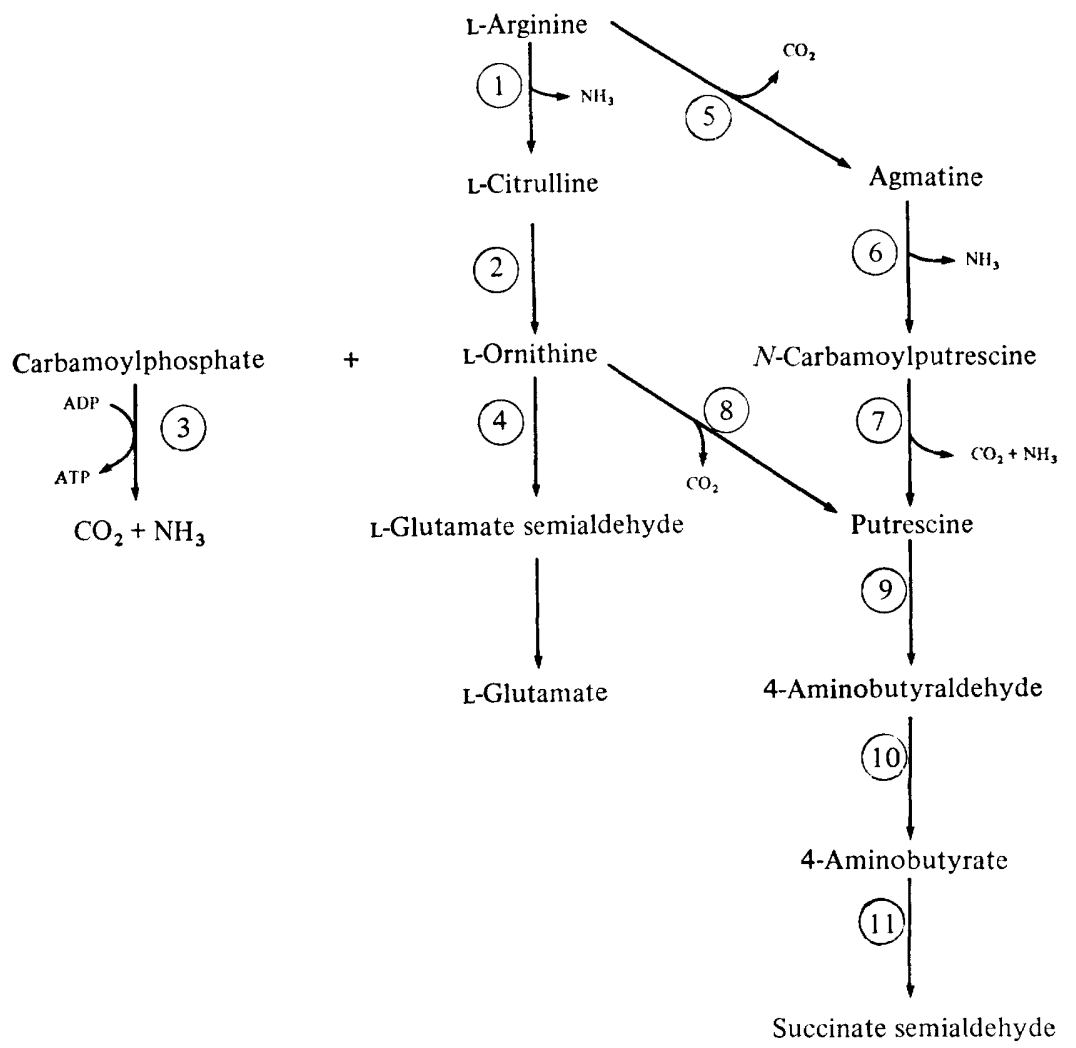

Fig. 1. Catabolic pathways for L-arginine in Pseudomonas aeruginosa: (1) L-arginine deiminase; (2) catabolic L-ornithine carbamoyltransferase; (3) carbamate kinase; (4) L-ornithine aminotransferase; (5) L-arginine decarboxylase; (6) agmatine deiminase; (7) $\mathrm{N}$-carbamoylputrescine amidinohydrolase; (8) L-ornithine decarboxylase; (9) 4-aminobutyrate aminotransferase; (10) 4-aminobutyraldehyde dehydrogenase; (11) 4-aminobutyrate aminotransferase. (Stalon et al., 1967; Voellmy \& Leisinger, 1975, 1976; Mercenier et al., 1980).

Miller \& Rodwell (1971) showed that $P$. putida could catabolize arginine by deamination to 2-oxoarginine followed by decarboxylation and removal of urea. The arginine deaminase and the arginase pathways (Broman et al., 1978) have not been reported in P. aeruginosa.

As part of our study on catabolic genes of $P$. aeruginosa we have isolated mutants that are unable to utilize L-arginine or L-ornithine as carbon sources for growth. We compared the activities of some of the enzymes of the catabolic pathways proposed for arginine in the wild-type and mutant strains of $P$. aeruginosa.

\section{METHODS}

Bacterial cultures. Media, strain maintenance, general cultural methods and techniques of genetic analysis were as described by Rahman \& Clarke (1980) using $\mathrm{L}$-arginine or L-ornithine in place of $\mathrm{L}$-lysine. Mutagenesis using $N$-methyl- $N^{\prime}$-nitro- $N$-nitrosoguanidine (NMG), and selection of mutants unable to use L-arginine for growth, followed the methods developed by Potts (1975) as modified by Rahman \& Clarke (1980). Wildtype strains and mutants are listed in Table 1 . The arginine utilization genes are designated as $a r u$, in accordance with Holloway et al. (1979). Revertants were isolated from L-arginine or L-ornithine plates and were obtained spontaneously or on plates carrying a small crystal of NMG.

Enzyme assays. These were carried out on cell extracts prepared from cultures harvested after about $16 \mathrm{~h}$ growth and resuspended in $0.01 \mathrm{M}$-phosphate buffer $\mathrm{pH} \mathrm{7.0.} \mathrm{Samples} \mathrm{were} \mathrm{assayed} \mathrm{as} \mathrm{soon} \mathrm{as} \mathrm{possible} \mathrm{or}$ kept frozen until required. Protein was assayed by the method of Lowry.

Arginine deiminase $(A D)$ (EC 3.5.3.6; L-arginine iminohydrolase) was assayed by the method of Ramos et al. (1967) by measuring the amount of citrulline produced from L-arginine. 
Table 1. Growth of Pseudomonas aeruginosa strains on minimal agar containing L-arginine and related compounds as carbon or nitrogen sources for growth

Growth on plates is indicated as +++ for good growth decreasing to + , with - indicating no growth. Plates were incubated at $37{ }^{\circ} \mathrm{C}$ for 3 to $4 \mathrm{~d}$.

\begin{tabular}{|c|c|c|c|c|c|c|c|c|c|c|}
\hline \multirow[b]{2}{*}{ Strain no. } & \multicolumn{9}{|c|}{ Additions to minimal agar* } & \multirow[b]{2}{*}{ Group } \\
\hline & $\begin{array}{c}\mathrm{Suc} / \\
\mathrm{NH}_{4}^{+}\end{array}$ & $\begin{array}{l}\text { Ace } / \\
\mathrm{NH}_{4}^{+}\end{array}$ & Arg & Orn & $\begin{array}{l}\text { Pyr/ } \\
\text { Arg }\end{array}$ & $\begin{array}{l}\text { Pyr/ } \\
\text { Orn }\end{array}$ & $\begin{array}{c}\text { Pyr / } \\
\text { Cit }\end{array}$ & Glu & Put & \\
\hline PACl & +++ & ++ & ++ & ++ & ND & ND & ++ & ++ & ND & \\
\hline PAT1 & +++ & ++ & ++ & ++ & ND & ND & ++ & ++ & ND & \\
\hline ATCC 7700 & +++ & ++ & ++ & ++ & ND & ND & ++ & ++ & ND & Wild-type \\
\hline 277 & +++ & ++ & ++ & ++ & ND & ND & ++ & ++ & ND & \\
\hline PAO1 & +++ & ++ & ++ & ++ & ND & $\mathrm{ND}$ & ++ & ++ & ND & \\
\hline PAO1632 & +++ & ++ & ++ & ++ & ++ & ++ & ++ & $+t$ & ++ & $\mathrm{Ami}^{-} \mathrm{Hut}^{-}$ \\
\hline PAO2051 & ++ & ++ & - & - & ++ & ++ & ++ & ++ & ++ & \\
\hline PAO2053 & +++ & ++ & - & - & ++ & ++ & ++ & ++ & ++ & \\
\hline PAO2054 & +++ & ++ & - & - & ++ & ++ & ++ & ++ & ++ & \\
\hline PAO2057 & +++ & ++ & - & - & ++ & ++ & ++ & ++ & ++ & I \\
\hline PAO2058 & +++ & ++ & - & - & ++ & ++ & ++ & ++ & ++ & \\
\hline PAO2059 & $+t+$ & ++ & - & - & ++ & ++ & ++ & ++ & ++ & \\
\hline PAO2096 & +++ & ++ & - & - & ++ & ++ & ++ & ++ & ++ & \\
\hline PAO2052 & ++ & ++ & - & - & + & + & + & ++ & + & \\
\hline PAO2055 & ++ & ++ & - & - & + & + & + & ++ & + & II \\
\hline PAO2056 & ++ & ++ & - & - & + & + & + & ++ & + & \\
\hline PAO2060 & +++ & ++ & - & ++ & + & ++ & ++ & ++ & ++ & III \\
\hline PAO2097 & +++ & ++ & - & + & + & ++ & & ++ & ++ & III \\
\hline PAO2061 & +++ & + & - & - & ++ & ++ & ++ & ++ & ++ & \\
\hline PAO2062 & $+t+$ & + & - & - & + & + & ++ & ++ & ++ & IV \\
\hline PAO2063 & +++ & + & - & - & ++ & ++ & ++ & ++ & $+t$ & \\
\hline
\end{tabular}

ND, Not determined.

* Additions to minimal agar: $\mathrm{Suc} / \mathrm{NH}_{4}{ }^{+}$, sodium succinate, $1 \%(\mathrm{w} / \mathrm{v})$, and $\left(\mathrm{NH}_{4}\right)_{2} \mathrm{SO}_{4}, 0 \cdot 1 \%(\mathrm{w} / \mathrm{v})$; Ace $/ \mathrm{NH}_{4}{ }^{+}$, sodium acetate, $0.3 \%(\mathrm{w} / \mathrm{v})$, and $\left(\mathrm{NH}_{4}\right)_{2} \mathrm{SO}_{4}, 0 \cdot 1 \%(\mathrm{w} / \mathrm{v}) ; \mathrm{Arg}$, arginine, $0 \cdot 2 \%(\mathrm{w} / \mathrm{v}) ; \mathrm{Orn}$, ornithine, $0.2 \%(\mathrm{w} / \mathrm{v}) ; \operatorname{Pyr} / \mathrm{Arg}$, pyruvate, $1 \%(\mathrm{w} / \mathrm{v})$, and arginine, $0.1 \%(\mathrm{w} / \mathrm{v}) ;$ Pyr/Orn, pyruvate, $1 \%$ $(\mathrm{w} / \mathrm{v})$, and ornithine, $0 \cdot 1 \%(\mathrm{w} / \mathrm{v}) ;$ Pyr $/$ Cit, pyruvate, $1 \%(\mathrm{w} / \mathrm{v})$, and citrulline, $0.1 \%(\mathrm{w} / \mathrm{v})$; Glu, glutamate, $0 \cdot 2 \%(\mathrm{w} / \mathrm{v})$; Put, putrescine, $0 \cdot 1 \%(\mathrm{w} / \mathrm{v})$.

Catabolic ornithine carbamoyltransferase (cOTC) (EC 2.1.3.3; carbamoylphosphate:L-ornithine carbamoyltransferase) was measured by the method of Stalon et al. (1972) in the direction of citrulline synthesis. Citrulline produced by AD and cOTC was assayed in an amino acid analyser (Locarte, London) using a short programme.

Acetylornithine aminotransferase $(A C O A T)$ (EC 2.6.1.11; $N^{2}$-acetyl-L-ornithine:2-oxoglutarate aminotransferase) was assayed by the method of Voellmy \& Leisinger (1975) with $N$-acetylornithine and 2-oxoglutarate as substrates, except that the colorimetric estimation of glutamic semialdehyde was replaced by measuring glutamate in the amino acid analyser.

Uptake of L-arginine. This was measured by the method used by Rahman \& Clarke (1980) for L-lysine.

\section{RESULTS}

Pseudomonas aeruginosa strains PAO, PAC and three other wild-type strains grew well on minimal agar plates with L-arginine or L-ornithine as sole nitrogen and carbon sources (Table 1). None grew well with citrulline alone but all grew with citrulline as nitrogen source and pyruvate as carbon source. This suggested that the rate of citrulline uptake might limit its utilization as carbon source.

Arginine utilization-negative mutants were isolated from strain PAO1632 (Hut-Ami-) which has the same arginine growth phenotype as the wild-type PAO1 (Table 1). Many of the mutants selected as minute colonies from arginine plates proved to be leaky, or to revert at a high rate, and were discarded. The 15 stable mutants that were unable to utilize 
Table 2. Transductional analysis of mutants of Pseudomonas aeruginosa unable to utilize $\mathrm{L}$-arginine as a carbon source for growth

The results show the numbers of transductants per $10^{9}$ recipient bacteria recovered on minimal agar plates with L-arginine as sole growth substrate.

$\begin{array}{cl}\text { Group } & \text { Strain no. } \\ \text { I } & \text { PAO2054 } \\ \text { I } & \text { PAO2057 } \\ \text { I } & \text { PAO2059 } \\ \text { III } & \text { PAO2060 } \\ \text { IV } & \text { PAO2061 } \\ \text { ser-2 } & \text { PAO2 }\end{array}$

\begin{tabular}{lll}
$\overbrace{\text { PAO1 632 }}$ & \multicolumn{1}{c}{ Donor strain } \\
\cline { 2 - 3 } 1560 & PAO2057 & PAO205y \\
1600 & 130 & 140 \\
3590 & 0 & 120 \\
1400 & 160 & 0 \\
1500 & 150 & 130 \\
2000 & 120 & 130 \\
\hline 1800 & 1850
\end{tabular}

Table 3. Plate mating of Pseudomonas aeruginosa mutants unable to utilize L-arginine as a carbon source for growth

Recombination frequencies are expressed as the numbers of recombinants per $10^{9}$ recipient bacteria on minimal agar plates containing the selective carbon sources. The donor strain was PAO381 $\left(\right.$ leu-38 FP2 $\left.{ }^{+}\right)$.

\begin{tabular}{|c|c|}
\hline \multicolumn{2}{|c|}{ Recipient strain } \\
\hline Group & Strain no. \\
\hline - & PAO1632 \\
\hline I & PAO2051 \\
\hline I & PAO2054 \\
\hline I & PAO2057 \\
\hline I & PAO2059 \\
\hline II & PAO2052 \\
\hline III & PAO2060 \\
\hline IV & PAO2062 \\
\hline
\end{tabular}

$\begin{array}{ccc}\text { Additions to minimal agar plates } \\ \text { Histidine } & \text { Arginine } & \text { Acetamide } \\ -10 \times 10^{4} & & 15-22 \times 10^{2} \\ -10 \times 10^{4} & 3-8 \times 10^{3} & 10-20 \times 10^{2} \\ 4-8 \times 10^{4} & 1-5 \times 10^{3} & 8-15 \times 10^{2} \\ -10 \times 10^{4} & 2-5 \times 10^{3} & 8-30 \times 10^{2} \\ -12 \times 10^{4} & 3-8 \times 10^{3} & 10-40 \times 10^{2} \\ 1-3 \times 10^{3} & 4-8 \times 10^{2} & 2-4 \times 10^{1} \\ 1-3 \times 10^{4} & 1-2 \times 10^{3} & \mathrm{ND} \\ 2-5 \times 10^{4} & 1-3 \times 10^{3} & 6-10 \times 10^{2}\end{array}$

ND, Not determined.

L-arginine as a carbon source were tested for growth on some of the postulated intermediates of the pathways proposed for arginine catabolism. In Table 1 they have been assigned to four phenotypic groups. Group I mutants were unable to utilize either L-arginine or Lornithine but grew well on the other test media. Group III were distinguished by growth on L-ornithine. The mutants assigned to group II were similar to those of group I but grew rather more slowly on all the test media and the mutants of group IV grew rather more slowly on acetate. The differences between mutants of groups I, II and IV could have been due to additional mutations since all were derived by NMG mutagenesis.

\section{Transductional analysis}

The rapid quarter-plate method (Day, 1975; Rahman \& Clarke, 1980) was used to obtain preliminary estimates of transduction frequencies. With donor lysates prepared with bacteriophage F116 on strains PAO1 and PAO1632 the normal value for wild-type transduction was obtained with all the mutants except those of growth phenotype group II.

The three mutants of group II gave no transductants with either donor and were also unable to propagate bacteriophage F116. This suggested that in addition to the genetic 


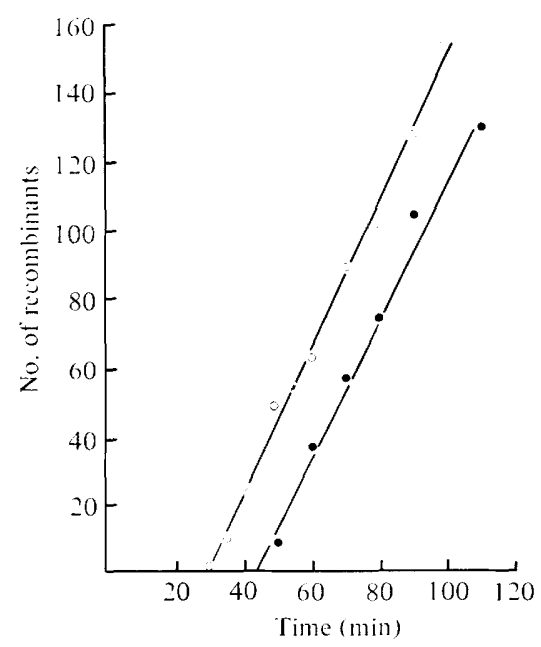

Fig. 2. Interrupted mating experiment with donor strain PAO381 (leu-38, FP2+, Aru+, E79 ${ }^{\mathrm{S}}$ ). Recombinants from crosses with PAO2057 (hutU, aru-107, E79 ${ }^{\mathrm{R}}$ ) were selected on L-histidine $(O)$ and L-arginine (O) plates. The numbers of recombinants are mean values for plates carrying $2 \times 10^{8}$ donor bacteria, using the method of Day et al. (1975).

defect resulting in inability to utilize L-arginine they had acquired another mutation related to surface properties.

Mutants of groups I, III and IV gave normal transduction frequencies (about 30 transductants) in the quarter-plate transduction with PAO1 and PAO1632 as donors but few transductants in reciprocal crosses with each other (about 3 to 4). These results were confirmed by the standard transduction method (Table 2). With PAO1632 as donor the numbers of transductants obtained with five aru mutants of groups I, III and IV were similar to that found for an auxotrophic marker, ser-2, with PAO2 as recipient. In transduction with two of the aru mutants as donors and strain $\mathrm{PAO} 2$ as recipient the transduction frequency was the same as with PAO1632 as donor. The reciprocal crosses between the aru mutants gave much lower transduction frequences indicating genetic linkage. These results suggested that the L-arginine utilization mutations of all the mutants shown in Table 2 were either in the same gene or in closely linked genes.

\section{Plate mating}

Plate mating with the donor strain PAO381 (leu-38 FP2 $\left.{ }^{+}\right)$was used to give a preliminary indication of the map position of the mutations (Day et al., 1975; Rahman \& Clarke, 1980). Table 3 shows the recombination frequencies for the aru genes compared with the hut and ami genes in the same crosses. The recovery of recombinants on L-arginine plates was intermediate between the numbers obtained on histidine and acetamide plates, indicating that the gene defects concerned with arginine catabolism were located between hutU and ami on the chromosome. The exception was PAO2052 (group II) which gave lower numbers of recombinants on all selective media. Strain PAO2052 is unable to propagate bacteriophage F116 or to act as a recipient in transduction. The surface mutation of this strain has also altered its conjugal efficiency. The contraselective marker of strain PAO381 was leu-38 located at about $50 \mathrm{~min}$ and if the aru marker is very close the recombination frequencies would have been depressed. Plate matings were repeated with PAO1815 (his-I FP5+) and PAO2700 (ser-3 FP2+) (see Holloway et al., 1979, for map positions) and PAO2054 and PAO2059 as recipients. The recombination frequencies were similar to those found with PAO381 as donor. 
Table 4. Activities of arginine catabolic enzymes in wild-type and mutant strains of Pseudomonas aeruginosa

\begin{tabular}{|c|c|c|c|c|}
\hline \multirow{3}{*}{$\begin{array}{l}\text { Strain and phenotype* } \\
\text { PAO1 } \\
\text { (Wild-type, } \mathrm{A}^{+} \mathrm{O}^{+} \text {) }\end{array}$} & \multirow{3}{*}{$\begin{array}{l}\text { Additions to medium } † \\
\text { Glutamate } \\
\text { Glutamate + arginine }\end{array}$} & \multicolumn{3}{|c|}{$\begin{array}{c}\text { Enzyme activity } \\
{[\mu \mathrm{mol} \text { substrate converted }} \\
\left.\mathrm{h}^{-1}(\mathrm{mg} \text { protein })^{-1}\right]\end{array}$} \\
\hline & & $\mathrm{AD}$ & cOTC & ACOAT \\
\hline & & $\begin{array}{r}0 \cdot 9 \\
13 \cdot 0\end{array}$ & $\begin{array}{r}40 \\
116\end{array}$ & $\begin{array}{r}2 \cdot 0 \\
15 \cdot 0\end{array}$ \\
\hline $\begin{array}{l}\text { PAO1632 } \\
\left(\mathrm{Ami}^{-} \mathrm{Hut}^{-}, \mathrm{A}^{+} \mathrm{O}^{+}\right)\end{array}$ & $\begin{array}{l}\text { Glutamate } \\
\text { Glutamate + arginine }\end{array}$ & $\begin{array}{l}0 \cdot 7 \\
7 \cdot 0\end{array}$ & $\begin{array}{l}22 \\
77\end{array}$ & $\begin{array}{r}3 \cdot 0 \\
18 \cdot 5\end{array}$ \\
\hline $\begin{array}{l}\mathrm{PAO} 2057 \\
\left(\mathrm{I}, \mathrm{A}^{-} \mathrm{O}^{-}\right)\end{array}$ & $\begin{array}{l}\text { Glutamate } \\
\text { Glutamate }+ \text { arginine }\end{array}$ & $\begin{array}{l}1 \cdot 3 \\
1 \cdot 8\end{array}$ & $\begin{array}{l}63 \\
65\end{array}$ & $\begin{array}{l}2 \cdot 0 \\
2 \cdot 5\end{array}$ \\
\hline $\begin{array}{l}\text { PAO2052 } \\
\left(\mathrm{II}, \mathrm{A}^{-} \mathrm{O}^{-}\right)\end{array}$ & $\begin{array}{l}\text { Glutamate } \\
\text { Glutamate + arginine }\end{array}$ & $\begin{array}{l}0.9 \\
0 \cdot 6\end{array}$ & $\begin{array}{l}34 \\
19\end{array}$ & $\begin{array}{l}1 \cdot 4 \\
2 \cdot 0\end{array}$ \\
\hline $\begin{array}{l}\text { PAO2060 } \\
\left(\text { III, } \mathrm{A}^{-} \mathrm{O}^{+}\right)\end{array}$ & $\begin{array}{l}\text { Glutamate } \\
\text { Glutamate + arginine }\end{array}$ & $\begin{array}{l}0 \cdot 8 \\
3 \cdot 0\end{array}$ & $\begin{array}{l}32 \\
56\end{array}$ & $\begin{array}{r}4 \cdot 0 \\
17 \cdot 0\end{array}$ \\
\hline
\end{tabular}

* Roman numbers refer to the phenotype groups of Table 1; growth on arginine (A) or ornithine $(O)$ is shown by the plus or minus superscript.

$\dagger$ Cultures were grown in minimal salt medium with additions as follows: glutamate, $0.5 \%(\mathrm{w} / \mathrm{v})$; arginine, $0 \cdot 1 \%(w / v)$.

\section{Interrupted mating}

Strain PAO381 (leu-38 $\left.\mathrm{FP}^{+}\right)$was used as the donor in interrupted mating experiments with PAO2057 (group I) made resistant to phage E79. Figure 2 shows the time of entry for hut $U$ at about 30 min confirming the results of Day et al. (1975). The curves for aru-107 gave a value of around $50 \mathrm{~min}$ and a similar entry time was found with another mutant. Transduction and conjugation indicated close linkage of the $a r u$ mutations and it was concluded that they were all located in this region. More accurate determination of the map position of these loci will require the use of other donor strains with contraselective markers remote from $a r u$ and the establishment of transduction linkage to known markers in this region.

\section{Enzyme activities}

Arginine deiminase (AD), catabolic ornithine carbamoyltransferase (cOTC) and $\mathrm{N}$ acetylornithine 5-aminotransferase (ACOAT) (see Fig. 1) were induced in strains PAO1 and PAO1632 after growth in L-arginine medium. Additional carbon sources, such as succinate, repressed synthesis but additional ammonia had no appreciable effect. There were no significant differences between strains PAO1 and PAO1632, and it was concluded that PAO1632 had the wild-type phenotype with respect to these catabolic enzymes.

Enzyme activities of PAO1 and PAO1632 were maximal in cultures grown with Larginine as sole carbon source but this medium could not be used with the mutants. Minimal salt medium containing $0.5 \%(\mathrm{w} / \mathrm{v})$ glutamate was used for non-induced cultures with $0 \cdot 1 \%(\mathrm{w} / \mathrm{v})$ L-arginine added for induced cultures. This resulted in lower enzyme activities for the wild-type strains but allowed the mutants to grow at a similar rate to the parental strains and gave satisfactory discrimination between the induced and non-induced states.

Table 4 compares the enzyme activities of PAO2057 (group I), PAO2052 (group II) and PAO2060 (group III) with those of strains PAO1 and PAO1632. AD, cOTC and ACOAT activities were detected in non-induced cultures of the three mutant strains so that it was clear that the inability to utilize arginine could not be ascribed to the loss of any of these enzymes. AD was induced about 10 -fold by L-arginine in cultures of PAO1 and PAO1632 but was not induced to a significant extent in any of the mutants. COTC had a high noninduced level in parental and mutant strains but, while it was induced to higher levels in PAO1 and PAO1632, there was no further induction in the mutant strains. The activity of 
Table 5. Enzyme activities of Pseudomonas aeruginosa mutant PAO2052 and revertants PAO2099 and PAO2100

\begin{tabular}{|c|c|c|c|c|}
\hline \multirow[b]{2}{*}{ Strain and phenotype* } & \multirow{3}{*}{$\begin{array}{l}\text { Additions to medium* } \\
\text { Glutamate } \\
\text { Glutamate+arginine }\end{array}$} & \multicolumn{3}{|c|}{$\begin{array}{c}\text { Enzyme activity } \\
{[\mu \text { mol substrate converted }} \\
\left.\mathrm{h}^{-1}(\mathrm{mg} \text { protein })^{-1}\right]\end{array}$} \\
\hline & & $\mathrm{AD}$ & cOTC & COAT \\
\hline $\mathrm{PAO} 2052 \quad\left(\mathrm{~A}^{-} \mathrm{O}^{-}\right)$ & & $\begin{array}{l}3 \cdot 0 \\
3 \cdot 0\end{array}$ & $\begin{array}{l}29 \\
22\end{array}$ & $\begin{array}{l}4 \\
4\end{array}$ \\
\hline PAO2099 $\left(\mathrm{A}^{+} \mathrm{O}^{+}\right)$ & $\begin{array}{l}\text { Glutamate } \\
\text { Glutamate }+ \text { arginine }\end{array}$ & $\begin{array}{l}2 \cdot 0 \\
2 \cdot 0\end{array}$ & $\begin{array}{l}14 \\
14\end{array}$ & $\begin{array}{l}10 \\
10\end{array}$ \\
\hline $\mathrm{PAO} 2100 \quad\left(\mathrm{~A}^{+} \mathrm{O}^{+}\right)$ & $\begin{array}{l}\text { Glutamate } \\
\text { Glutamate + arginine } \\
\quad * \text { See Table } 4 .\end{array}$ & $\begin{array}{l}2 \cdot 0 \\
2 \cdot 0\end{array}$ & $\begin{array}{r}15 \\
9\end{array}$ & $\begin{array}{l}10 \\
18\end{array}$ \\
\hline
\end{tabular}

the aminotransferase was measured with $N$-acetylornithine as ACOAT activity. Voellmy \& Leisinger (1975) found that the enzyme acted as an aminotransferase with both $N$-acetylornithine and ornithine with a ratio of ACOAT to OAT activities of about 4:1. ACOAT activity was induced by L-arginine in strains PAO1 and PAO1632 but was not induced in strains PAO2057 and PAO2052. Strain PAO2060 (which could grow on ornithine but not on arginine) was induced by L-arginine to about the same extent as the parental strains.

The non-induced levels of the first two enzymes were sufficient to account for growth with arginine as nitrogen source and the non-induction of arginine deiminase in the mutant strains provided a possible explanation of the inability to utilize L-arginine as a carbon source. A threshold level of ACOAT appeared to be required since the mutant capable of growth with L-ornithine (PAO2060) could be induced by arginine to an activity comparable with those of the parental strains. ACOAT activity was also induced by ornithine in strain PAO2060. The results suggested that the defects responsible for inability to utilize arginine might be in regulatory genes rather than in structural genes.

\section{Uptake of L-arginine}

The altered regulation of the arginine catabolic enzymes in the mutants could have been due to the impairment of uptake of L-arginine. If a high threshold value were required before the enzymes could be induced, then with a very low rate of uptake of L-arginine and L-ornithine this level might not be reached. L-Arginine uptake was measured by the method used by Rahman \& Clarke (1980) for L-lysine. Strains PAO1, PAO1632 and group I mutants were found to have active arginine transport systems. The rates of uptake of strains PAO2052 and PAO2056 (group II) were lower although sufficient for growth with L-arginine as nitrogen source. Transduction and conjugation experiments with mutants of group ${ }^{\top} \mathrm{II}$ had suggested that they were affected in surface properties. They grew more slowly than the other mutants on all test media and the reduced rate of uptake of L-arginine by mutants of group II may be due to alterations in membrane structure rather than to specific defects in the arginine uptake system.

\section{Enzyme activities of arginine utilization-positive revertants}

Mutants PAO2057, PAO2052 and PAO2060 were plated on minimal agar containing L-arginine or L-ornithine to select revertants. One stable revertant from PAO2052 arose spontaneously on L-arginine medium and one on L-ornithine medium. Both revertants had acquired the ability to grow on both amino acids. Further revertants were recovered by NMG mutagenesis of all three strains. In a total of 21 tested, 19 were able to grow on 
both L-arginine and L-ornithine irrespective of which amino acid had been used for selection and two revertants grew slowly on L-arginine and not at all on L-ornithine.

The two spontaneous revertants of strain PAO2052 were selected for enzyme studies. Table 5 gives the values for AD, cOTC and ACOAT activities of revertant PAO2099 (isolated on L-arginine), revertant PAO2100 (isolated on L-ornithine) and mutant PAO2052. In this experiment the basal level of $\mathrm{AD}$ of PAO2052 was higher than in the previous series of experiments and this may have been due to a slight difference in aeration rate (Mercenier et al., 1980). Mutant PAO2052 and the two revertants were non-inducible for AD. The cOTC activities were also non-inducible and the activities of the revertants were lower than for PAO2052 and markedly lower than for PAO1 and PAO1632 (Table 4). The ACOAT activities of both revertants were significantly different from mutant PAO2052. The induced activities were comparable to the induced levels of the wild-type strains grown in this medium and the basal non-induced levels were also high. The revertants had regained the ability to utilize arginine and had higher specific activities for ACOAT but, unlike the wild-type, the synthesis of ACOAT was partially or completely constitutive.

The results can be explained if the original mutation giving the arginine utilizationnegative phenotype were in a regulatory gene controlling the synthesis of ACOAT. The reversion could be a result of a second regulatory mutation. The mutant strain PAO2052 was also non-inducible for the enzymes AD and cOTC and these activities were not increased in the revertants suggesting that the regulatory systems for these arginine catabolic enzymes may involve the interactions of more than one regulatory gene.

\section{DISCUSSION}

We suggest that the reason why our mutants are unable to utilize L-arginine as a carbon source is that the activities of ornithine aminotransferase (ACOAT/OAT) are too low. The importance of ACOAT in arginine catabolism had been indicated previously by Voellmy \& Leisinger (1976). They screened 3000 colonies of a mutagenized culture of $P$. aeruginosa and found a single clone lacking both ACOAT and OAT activity. This strain was unable to grow on L-ornithine and produced only faint growth on L-arginine. Spontaneous revertants, selected on L-ornithine, had the same ACOAT/OAT specific activities as the wild-type strain. They concluded that the mutant was defective in $\arg D$, the structural gene for ACOAT, and that this enzyme had both anabolic and catabolic roles. The mutant was not auxotrophic for arginine since the ACOAT activity of 4-aminobutyrate aminotransferase (GABAT) was sufficient for arginine biosynthesis.

Our results support the findings of Voellmy \& Leisinger (1976) on the key role of the $\arg D$ enzyme in arginine catabolism but none of our mutants had lost all ACOAT activity and we concluded that the mutations were in a regulatory gene rather than in the structural gene. We confirmed that ACOAT is induced by L-arginine and L-ornithine and repressed by alternative growth substrates. One of the mutants that had become non-inducible for ACOAT gave rise to constitutive revertants and this result would be consistent with a mutation and a reversion in a regulatory gene for the enzyme. It would be more likely to occur if the regulatory gene product exerted positive control on gene transcription (Farin \& Clarke, 1978). This interpretation does not take into account the non-inducibility of AD and COTC in the arginine utilization-negative mutants. The three enzymes are induced by L-arginine (and L-ornithine) and a mutation in a common regulatory gene might affect all three enzymes. If this were the case, the two revertants examined might have had mutations in the specific operator-promoter region for ACOAT since AD and COTC remained non-inducible.

An apparent contradiction of the essential role of ACOAT was the finding of Haas et al. (1979) that a mutant totally lacking cOTC activity was able to grow at the wild-type rate on L-arginine. Mercenier et al. (1980) demonstrated that the three enzymes of the alternative 
arginine decarboxylase pathway (Fig. 1, enzymes 5, 6 and 7) were present in $P$. aeruginosa grown with arginine and suggested that this was the major pathway for arginine catabolism during aerobic growth. The existence of alternative pathways for arginine catabolism could account for the difficulty in isolating mutants for specific enzymes. We screened $4 \times 10^{5}$ colonies and isolated only 15 stable arginine utilization-negative strains, and all of those we examined appeared to have mutations in regulatory genes rather than in structural genes.

The occurrence of more than one catabolic pathway for a growth substrate is common among pseudomonads and the deciding factor is the specificity of the regulatory controls. For example, organisms with the genetic potential for both ortho and meta cleavage pathways for aromatic compounds may employ either, according to the growth substrate (Feist \& Hegeman, 1969; Williams \& Murray, 1974). If the arginine deiminase and arginine decarboxylase pathways are both potentially available for arginine catabolism we have to reconcile the finding of the apparently essential role of ACOAT with the dispensability of cOTC. The regulation of putrescine catabolism is relevant to this problem. The catabolism of putrescine (Fig. 1) requires two aminotransferase steps (9 and 11) and both may be carried out by GABAT. Voellmy \& Leisinger (1976) found that putrescine and 4-aminobutyrate were much more effective than arginine as inducers of GABAT synthesis. It is possible that our mutants (able to grow on putrescine but not arginine) are unable to produce enough putrescine from arginine to induce sufficient GABAT activity for the complete breakdown of arginine via the decarboxylase pathway. Our mutants produce ornithine from arginine by the residual activities of AD and cOTC, but Mercenier et al. (1980) found that ornithine decarboxylase is not induced by either arginine or ornithine so that this reaction could not provide an alternative route for putrescine production. In the mutant defective in cOTC (Haas et al., 1979) all the arginine would be channelled through the arginine decarboxylase pathway so that putrescine could reach a level sufficient for the induction of the enzymes for the later steps of the pathway. The requirement for a critical concentration of putrescine for the induction of the putrescine pathway enzymes could account both for the growth of the cOTC mutant on arginine and the lack of growth of mutants defective in ACOAT but possessing cOTC activity.

M.R. is grateful to the University of Dacca for a grant for study leave during which this work was carried out. We thank Mrs Renee Tata for excellent technical assistance in the isolation of mutants and Alison Sparrow for drawing the figures.

\section{REFERENCES}

Broman, K., Lauwers, N., Stalon, V. \& Wiame, J. M. (1978). Oxygen and nitrate in utilization by Bacillus licheniformis of the arginase and arginine deiminase routes of arginine catabolism and other factors affecting their synthesis. Journal of Bacteriology 135, 920-927.

DAY, M. (1975). Genetic studies with Pseudomonas aeruginosa strains. Ph.D. thesis, University of London.

Day, M., Potts, J. R. \& Clarke, P. H. (1975). Location of genes for the utilization of acetamide, histidine and proline on the chromosome of Pseudomonas aeruginosa. Genetical Research 25, 71-78.

Farin, F. \& Clarke, P. H. (1978). Positive regulation of amidase synthesis in Pseudomonas aeruginosa. Journal of Bacteriology 135, 379-392.

Feist, C. F. \& Hegeman, G. D. (1969). Phenol and benzoate metabolism by Pseudomonas putida: regulation of tangential pathways. Journal of Bacteriology 100, 869-877.
Haas, D., Holloway, B. W., Schamboeck, A. \& LEISINGER, TH. (1977). The genetic organisation of arginine biosynthesis in Pseudomonas aeruginosa. Molecular and General Genetics 154, 7-22.

HaAs, D., Evans, R., Mercenier, A., Simon, J.-P. \& Stalon, V. (1979). Genetic and physiological characterisation of Pseudomonas aeruginosa mutants affected in the catabolic ornithine carbamoyltransferase. Journal of Bacteriology 139, 713-720.

Holloway, B. W., Krishnapillai, V. \& Morgan, A. (1979). Chromosomal genetics of Pseudomonas. Microbiological Reviews 43, 73-102.

JACOBY, W. B. \& Fredericks, J. (1959). Pyrrolidine and putrescine metabolism: aminobutyraldehyde dehydrogenase. Journal of Biological Chemistry 234, 2145-2150.

Mercenier, A., Simon, J.-P., HaAs, D. \& Stalon, V. (1980). Catabolism of L-arginine by Pseudomonas aeruginosa. Journal of General Microbiology 116, 381-389. 
MilleR, D. L. \& Rodwell, V. M. (1971). Metabolism of basic amino acids in Pseudomonas putida. Journal of Biological Chemistry 246, 5053-5058.

Potrs, J. R. (1975). Histidine catabolism in Pseudomonas aeruginosa. Ph.D. thesis, University of London.

Rahman, M. \& Clarke, P. H. (1980). Genes and enzymes of lysine catabolism in Pseudomonas aeruginosa. Journal of General Microbiology 116, 357-369.

Ramos, F., Stalon, V., Pierard, A. \& Wiame, J. M. (1967). The specialization of the two ornithine carbamoyltransferases of Pseudomonas. Biochimica et biophysica acta 139, 98-106.

Shoesmith, J. G. \& Sherris, J. C. (1960). Studies on the mechanism of arginine-activated motility in a Pseudomonas strain. Journal of General Microbiology 22, 10-24.

Stalon, V., Ramos, F., Piérard, A. \& Wiame, J. M. (1967). The occurrence of a catabolic and an anabolic ornithine carbamoyltransferase in Pseudomonas. Biochimica et biophysica acta 139, 91-97.

Stalon, V., Ramos, F., Piérard, A. \& Wiame, J. M. (1972). Regulation of the catabolic ornithine carbamoyltransferase in Pseudomonas fuorescens. European Journal of Biochemistry 29, 25-35.
Stalon, V., Legrain, C. \& Wiame, J. M. (1977). Anabolic ornithine carbamoyltransferase of Pseudomonas. The bases of its functional specialization. European Journal of Biochemistry 74, 319327.

Stanier, R. Y., Palleroni, N. J. \& Doudoroff, M. (1966). The aerobic pseudomonads: a taxonomic study. Journal of General Microbiology 43, 159 271.

Voellmy, R. \& Leisinger, TH. (1972). Regulation of enzyme synthesis in the arginine system of Pseudomonas aeruginosa. Journal of General Microbiology 73, xiii.

Voellmy, R. \& Leisinger, Th. (1975). Dual role for $N^{2}$-acetylornithine 5-aminotransferase from Pseudomonas aeruginosa in arginine synthesis and arginine catabolism. Journal of Bacteriology 122, 799-809.

Voellmy, R. \& Leisinger, TH. (1976). Role of 4 aminobutyrate aminotransferase in the arginine metabolism of Pseudomonas aeruginosa. Journal of Bacteriology 128, 722-729.

Williams, P. A. \& MurRay, K. (1974). Metabolism of benzoate and the methylbenzoates by Pseudomonas putida (arvilla) mt-2: evidence for the existence of a TOL plasmid. Journal of Bacteriology 120, 416-433. 